\title{
The Feminist-Solution Focused Counseling vs. Psychoeducational Model: Which One is Better?
}

\author{
Sigit Sanyata \\ Guidance and Counseling Department, \\ Faculty of Educational Science, \\ Universitas Negeri Yogyakarta, Indonesia
}

DOI: https://doi.org/10.36941/jesr-2020-o111

\begin{abstract}
Feminist-solution focused counseling (F-SFC) refers to the integration of approaches that focuses on the solution and problem. It can be applied to help counselees with any issues on gender inequality. However, the effectiveness of F-SFC compared to the psychoeducational model still needs to be tested. The experimental study was chosen to test whether F-SFC is more effective than the psychoeducational model. The gender equality scale was used for the pre-test and the posttest. The data was collected using the Delphi method to formulate the concept of gender equality. T-test and ANCOVA were utilized to test the hypotheses. The results showed that both F-SFC and psychoeducational model were found effective to help counselees with gender equality issues. The effectiveness of the feminist-solution focused counseling was determined by the consistency of counselor in holding the counseling based upon the guidance of F-SFC. The increases of the understanding about gender equality can be seen from the counselees' responses of the exceptional questions, miracle questions, scaling questions and coping questions in the counseling process. Meanwhile, the effectiveness of the psychoeducational model was determined by the design of materials, media and facilitators.
\end{abstract}

Keywords: solution focused, problem focused, feminist, gender, equality

\section{Introduction}

The development of counseling and psychotherapy strategies has shifted from problem-focused counseling to solution-focused counseling (Corey, 2009). The solution-focused brief therapy (S-FBT) is a short treatment that focuses on the attempt to create or develop the solutions of the counselee's problems (Lee, 2003; Lee, 2004; McKenna \& Jones, 2004; Smock, et al.., 2008; Mireau \& Inch, 2009; Sharf, 2012) and the responsible acts (Hsu \& Wang, 2011). The solution-focused counseling (SFC) helps a counselee to explore how the solution is done based on the power and positive hopes determining the success of counseling (Trepper, Dolan, McCollum \& Nelson, 2006; Corey, 2009; Mireau \& Inch, 2009) by reducing the current or future stressors (McKenna \& Jones, 2004) - but not to explore the problematic essence (Corey, 2009; Grant \& O'Connor, 2010). In SFBT, defining the counseling purpose is an essential phase; thus, the purpose is formulated concretely (Sharf, 2012) as something simple, realistic, and achievable (Dermer, et.al., 1998; Corey, 2009; Reiter, 2010; Hall, Rushing \& Khurshid, 2011). The purpose of counseling may differ for each counselee, as every counselee is unique (Corey, 2009). Each of counselee makes various purposes following their future life. To obtain a concrete purpose, the counselor needs to help a counselee 
to make the purpose declared positively and emphasize the process or action on today or future life, so that it can be achieved concretely, and controlled by the counselee (Corey, 2009).

Solution-focused counseling/SFC refers to an attempt to explore how the problem solution is done - not to explore the essence of problems (Corey, 2009; Grant \& O'Connor, 2010). The questions used in the therapy include miracle questions, exception questions (pretreatment change questions), scaling questions and coping questions (Neipp, Beyebach, Nunez \& Gonzalez, 2016). Meanwhile, the problem-focused counseling approach focuses more on exploring, analyzing, diagnosing, and coping with the problem (Sharry, 2007). One of the important aspects that need to be considered in problemfocused counseling is that it can take a long session, while the solution-focused counseling approach is relatively short and emphasizes on the problem solution. To the reason of the compatibility, the problem-focused and solution-focused counseling cannot be integrated to help counselee with gender issues. The only possible way to integrate both approaches is by applying both counseling approaches together but in separated session (Sharry, 2007).

The feminist counseling is a strategy to help counselee by adopting any counseling techniques (Sharf, 2012) and describing the counselee's issues to be gender-fair, multicultural flexible, interactive and life-oriented (Worell \& Remer, 2003; Corey, 2009). The basic strategies that make the feminist counseling are more effective include first, the counselor have to understand the gender-related issues; second, the attitude of counselor have to be able to encourage the process of gender equality socialization within the counseling process (Pilpot, Brooks, Lusterman \& Nutt (1997) in Hoffman, 2001). The two qualities enable feminist counseling to be integrated with other types of counseling approaches. The integration of the feminist counseling to the other theories can be seen in the concepts of feminist psychoanalytic theory, feminist behavioural and cognitive theory, feminist gestalt theory, feminist narrative therapy, feminist therapy, and counseling and brief therapy (Sharf, 2012)

Another approach that can be used in developing the understanding of the gender equality is psychoeducation that is seen effective in any attempts to cope with any social issues (Brown, 2004; Lukens \& McFarlane, 2004; Grant, 2012; Bore, Hendricks \& Womack, 2013). The psychoeducation approach is relatively flexible in coping with any various topics based on the potencies and focused on the future (Franklin, Moore \& Hopson, 2008). One of the advantages of psychoeducation approach is the competence in building the cognitive structure and positioning it as one of the strategies in empowering the members of the group particularly in building their cognitive perspectives (Corey, 2009). The psychoeducation group model aims to build a structure for interactions and interrelations by not making the discussion topic as the purpose of problem-solving. The psychosocial-process group model allows the group leader to facilitate the group members without burdening in their dominant cultural habits or approaches, attitudes, and values or beliefs. The focus of the psychoeducation group is on learning, discussing, self-adjusting and understanding group members' attitudes, values, their beliefs, ideas and opinions (Rivera, Wilbur, Phan, Garrett, \& Betz, (2004) by Bore, Hendricks \& Womack, (2013). The counselor's competences in developing a psychoeducation group can provide insightful knowledge and skills to the group members.

The solution-focused feminist approach emphasizes on the solutions; while the psychoeducation approach focuses on the problems. The solution-focused feminist counseling approach uses most of the time to discuss solutions; whereas the psychoeducation approach takes more time to discuss gender equality problems rather than its solutions. The discussion of solutions to point out the importance of a humanist approach by the counselor (Vela, et al., 2018). The uniqueness of the two approaches becomes the basis for comparing a solution-focused approach with a psychoeducation approach in overcoming the issues around gender equality.

Why gender equality is chosen as the manipulated variable? The emergence of the gender mainstreaming has been caused by the limited access to a variety of productive sources including economy, education and health. The principle of equality in terms of accessibility is based upon the competence of an individual to access knowledge, power, resources and important services based on their self-actualization and self-persistence (Crethar, Rivera \& Nash, 2008; Nasution et al., 2020). The limitation of access, control, participation and benefits has made one of the individuals tend to participate in a 
domestic domain that is potential to raise the issues about gender inequality. Gender inequality can be represented in professional responsibilities, manifested on the role of gender in general and in the inequality of the professional activities (Healey \& Hays, 2012), dysfunction of a system in family, career discrimination (Evans, et al., 2005), and violence against the women (Briere \& Jordan, 2004; Nasution et al., 2020). The gender-related issues still associate with the men power that is presented in many social theories (Diekman, Goodfriend \& Goodwin, 2004). The source of power is something indirectly as the source of control in social roles. The power sources become one of the choices in developing the social role; thus, both men and women have equal access (Nasution et al., 2020).

Although there are some changes in gender roles, women still have less power than men (Diekman, et al. 2004). An analysis in the perspective of social role theory explains that the differences in gender roles in terms of power will result in dominant access to men (Diekman, et al., 2004). The barriers to the construction of gender equality include socio-cultural barriers (Hermawati, 2007; Kercheval, 2012; Söderberg, 2020), structural, religious and legal interpretations. The two analyses of the causes of violence against women are patriarchal culture and social injustice (Evans, et al., 2005). Structural barriers are related to women's participation in politics and decision-making (Hermawati, 2007). Gender problems can be solved with various strategies that one of which is through counseling (Hackney \& Cormier, 2009). Blocher, (1974); Hackney \& Cormier, (2009) stated that each individual is in an ecological environment. Individuals exist in a cultural context and live with other individuals in an ecological system. The counseling process focuses on the ecological system that will intervene in the individual's environment. Worell \& Remer (2003) asserted that to solve gender issues, a counsellor must have an understanding of the context in which problems arise. To cope with gender equality problems, solution-focused feminist counseling was used. The used strategy is an integration of two approaches: a feminist counseling approach and a solution-focused counseling approach. Sharry (2007) recommended applying a solutionfocused counseling approach when conducting group counseling interventions.

\section{Method}

To test the effectiveness of F-SFC approach in facilitating gender-related issues, a sufficient instrument that can measure gender equality is needed. The scale of gender equality (SGE) was used in this study. The indicators of gender equality are determined by social construction; thus, it needs to be explored through the analysis of the experts in gender equality. The results from the instrument were used in the experiment process.

\subsection{Participants}

The research participants were the members of a community. The study used a mixed method design that was embedded experimental model. The design enables to present a set of data to support the conceptualization of the construct of gender equality using the Delphi method, and the results of the experiment in comparing the effectiveness between F-SFC and psychoeducational.

\subsection{Instrument}

The data collection of the experiment used the scale of gender equality (SGE), in which the increase of gender equality can be predicted by the solution-focused counseling process. The content validation of the gender equality scale was analyzed by using Aiken's $V$ to measure the content validity coefficient (Azwar, 2012). The reliability to the SGE-1 as a pretest was 0.800 and the reliability to the SGE-2 as a posttest was 0.839 .

\subsection{Experiment Design}

The experiment was conducted to compare the F-SFC group to the psychoeducational group (PG). The used strategy was a group counseling strategy. There were 6 groups as the sample groups that consist 
of five groups intervened with the solution-focused counseling approach and one group intervened with the solution-focused feminist counseling approach and one group used the psychoeducation approach. The data was analyzed by using means of a flowchart, t-test, and covariant analysis (Miles \& Huberman, 1984; Shavelson, 1988; Creswell, 2007; Creswell, 2009; Heppner, 2008; Furqon, 2009; Widhiarso, 2010a, 2010b, 2011).

Table 1: The experiment process of solution focused feminist counseling approach

\begin{tabular}{cccc}
\hline & Pretest (SGE-1) & Process & Posttest (SGE-2) \\
\hline Non-R & $\mathbf{O}_{\mathrm{Al}_{1}}$ & Feminist-solution focused group counseling & $\mathbf{O}_{\mathrm{B}_{2}}$ \\
Non-R & $\mathbf{O}_{\mathrm{A}_{3}}$ & Psychoeducational group method & $\mathbf{O}_{\mathrm{B}_{4}}$ \\
\hline
\end{tabular}

\subsection{Data Analysis}

The procedure of data analysis included qualitative and quantitative analysis. The data from Delphi method was collected through the interviews and discussions on the topic of gender equality in the perspective of the household. The quantitative analysis comprised three phases. The first phase was to assert that there was no difference between the experiment group and the control group in the gender equality perspectives. The second phase was to find the differences between the pretest results and the posttest results in both groups. The third phase was to compare the results of the posttest between the F-SFC group and Psychoeducational group by controlling the pretest variable. The analysis used in the phase was covariance analysis with one covariate.

\section{Results}

\subsection{Delphi Method}

The data was collected using the Delphi method by formulating the gender equality that referred to the chance to obtain equal access in any sectors, to contribute and to participate in any household roles, dan to interact under the concept of equity, accessibility, participation and harmony. However, the important point of building equality is determined by the commitment of the couple (husbandwife). First, access refers to the principle of social justice based upon the competence of an individual to access knowledge, power, resources and any important services in the daily life; thus, it enables the self-actualization and self-determination. The access related to the resources is the chance to career development. Second, participation is a dimension about earning a living, involvement in decision making determining the daily life, socialization and cultural flexibility (Crether, Rivera \& Nash, 2008). The significant participation of each family member is based upon an assumption that the lack of participation tends to lose the control that can trigger the feeling of hopelessness, powerlessness as well as having no rights to speak up in the household. Furthermore, the situation can impact on the physical and emotional health. Crether, Rivera \& Nash (2008) recommended two measures to deal with the problem in participation including a) counselor is responsible for empowering the counselee through the provision of understanding about the rights of family participation, and b) the counselor assists the counselee in developing the practical strategies in the family.

Third, equity has a principle of justice distribution between rights and obligations. It is correlated to the proportion between input and output, equal condition, and coincided with ability, efforts, and skill, equal opportunity (if competing), coincided with the community demands and coincided with the mutualism principle (Crether, Rivera \& Nash, 2008). The mutualism principle is taken from the distributive justice, in which the right of fulfilment is based upon the needs - not the similarities. The fourth dimension of gender equality is a harmony that is defined as an individual condition that has a contribution to the family to support each other. The concept of harmony is based on the needs and rights of family members to have a role. Harmony is based on a principle that social justice is adjusted 
with the needs and rights of each individual following the context of community needs. The results of Delphi method showed that the concept of equity was correlated to justice. Crether, Rivera \& Nash (2008) explained that social justice at least contains two meanings: a) equal rights and fundamental freedom, b) distribution of equality in resources and chance. Justice will bring an impact on human existence in the personal and social domains.

\subsection{The Stages of Experiment}

In step 1, the assessment was conducted before the intervention. It was to ascertain that there was no difference between the control group and experiment group through the pretest (SGE-1). The result of $t$-test showed that the $t$ value was 0,$970 ; p>0,05$. It can be concluded that there was no significant difference between the experiment group and the control group. In step 2, the results of pretest and posttest were compared to ascertain whether there was an increase in both the control group and experiment group. The pretest and posttest scores for the experiment group were analyzed by the independent sample $t$-test that showed $t_{(30)}=-5,960 ; p<0,05$. The result showed that there was a difference between pretest and posttest scores in the experiment group. The independent sample t-test also used to analyze the control group. The result showed $t_{(31)}=-3,206 ; p<0,05$; thus, there was no difference between the scores of pretest and posttest.

Table 2: The differences of pre-test and posttest between F-SFC and PG group

\begin{tabular}{|c|c|c|c|c|c|c|c|}
\hline & \multicolumn{5}{|c|}{ Paired Differences } & \multirow{3}{*}{ 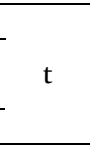 } & \multirow{3}{*}{ Df $\underset{\text { (2-tailed) }}{\text { Sig. }}$} \\
\hline & \multirow[t]{2}{*}{ Mean } & \multirow[t]{2}{*}{ Std. Deviation } & \multirow{2}{*}{ Std. Error Mean } & \multicolumn{2}{|c|}{$\begin{array}{c}95 \% \text { Confidence } \\
\text { Interval of the Difference } \\
\end{array}$} & & \\
\hline & & & & Lower & Upper & & \\
\hline Pair 1 FSFC-Pre FSFC-Post & $-33 \cdot 500$ & 30.785 & 5.621 & -44.995 & -22.005 & -5.960 & .000 \\
\hline $\begin{array}{ll}\text { Pair } 1 & \text { PG-Pre } \\
\text { PG-Post }\end{array}$ & -25.742 & $44 \cdot 709$ & 8.030 & -42.141 & $-9 \cdot 343$ & -3.206 & .003 \\
\hline
\end{tabular}

Both F-SFC approach and psychoeducation approach were effective to help counselees' who had gender-related issues with a similar impact. The test of hypothesis found the effect of treatment using the analysis of covariant by comparing the posttest scores and controlling the pretest scores. The first pre-requirements of ANCOVA can show the interaction between the groups using the pretest scores. One of the requirements in ANCOVA is the insignificant interaction between treatment groups by the results of pretest scores. The results of the analysis showed that the interaction between the groups by the pretest scores was not significant $\left(\mathrm{F}_{(61)}=13.116\right.$; $\left.\mathrm{p}<0.05\right)$. Second, there was no difference in variance either in experiment group or in the control group $\left(\mathrm{F}_{(61)}=1,774 ; \mathrm{p}>0,05\right)$; thus, the analysis of covariance can be conducted.

Table 3: The test on the effectiveness towards the groups

Dependent Variable: Posttest

\begin{tabular}{lcccccc}
\hline Source & Type III Sum of Squares & df & Mean Square & F & Sig. & Partial Eta Squared \\
\hline Corrected Model & $2244.654^{\mathrm{a}}$ & 2 & 1122.327 & $\mathbf{1 . 7 6 2}$ & .181 & .057 \\
Intercept & 64823.294 & 1 & 64823.294 & 101.746 & .000 & .637 \\
Group & 3.632 & $\mathbf{1}$ & 3.632 & .006 & .940 & .000 \\
Pretest & $\mathbf{2 2 2 8 . 3 4 1}$ & 1 & $\mathbf{2 2 2 8 . 3 4 1}$ & 3.498 & .067 & .057 \\
Error & 36952.494 & 58 & 637.112 & & & \\
Total & 4769102.000 & 61 & & & & \\
Corrected Total & 39197.148 & 60 & & & & \\
\hline
\end{tabular}

a. R Squared = ,o57 (Adjusted R Squared = ,025) 
The results of ANCOVA analysis showed that there was no difference in the scores of posttest between the experiment group and control group $\left(\mathrm{F}_{(61)}=0,006 ; \mathrm{p}>0,05\right)$. No difference showed a conclusion that the approaches of F-SFC and psychoeducation are equally impacting on the increase of gender equality. This can be explained from the contribution scores of experiment group that was relatively low. Based on the adjusted R squared, the contribution of F-SFC in increasing the gender equality was 2,5\%; however, if it was seen from the scores of partial eta squared, the contribution of $2,5 \%$ was viewed as meaningless. It can be concluded that both approaches of F-SFC and PG were proven effective in increasing gender equality in counseling.

\section{Discussion}

The development of gender-based counseling is based on several factors. The first is the dissatisfaction of the treatment given by the traditional approaches as a criticism for the process of mental health therapy (Worell \& Remer, 2003; Evans, et al. 2005). Second, the mental health must consider the sex, gender and cultural differences in terms of prevalence, etiology, diagnose and therapy action (Biasi, et.al. 2020; Pratikta, 2020). Third, both men and women have different characteristics of mental health. The emergence of feminist therapy becomes the answer for any limitations in a traditional approach that later on is compatible with traditional, modern and post-modern approaches. In its development, feminist therapy is integrated with the concept of other theories. One of the integrations is the positivefeminist therapy that is a development of feminist therapy based upon the strength of local wisdom. The therapy is an integration of feminist therapy, system theory and positive psychology (Tzou, Kim \& Waldheim, 2012). Feminist-Solution-focused counseling believes that counselees have competence and strength in facing any problems related gender (Dermer, Hemesath \& Russel, 1998). The counseling approach can be applied in any settings in counseling including to the perspective and multicultural development and integration with other approaches (eclectic) (Guterman \& Leite, 2006). Solutionfocused views that each individual has potency, strength and skill in problem-solving and ignores any gender differences (Guterman \& Leite, 2006). However, the solution-focused can still be possible to integrate with feminist counseling and behavioral-cognitive approach (Sharry, 2007)

Similar with the positive-feminist therapy, the approach of feminist-solution focused group counseling is an integration of two approaches: feminist counseling and solution-focused counseling. Feminist counseling is an effort of social deconstruction of gender roles that aims to build the concept of equity through the analysis of gender role. Meanwhile, solution-focused counseling is as a strategy to cope with any drawbacks in understanding gender roles. Crethar, Torres \& Nash (2008) confirmed that the concept of feminist counseling approach is different from the traditional perspectives. Worell \& Remer (2003) mentioned that feminist counseling is an empowerment model. The strategy that can be done to build the awareness of gender is through the analysis of gender roles. Awareness is developed from the understanding of reflective training (Dimmit, 2005; Chao, 2012; Balkin, 2018). Nevertheless, the fundamental point of a feminist counselor is the humanistic figure of counselor (Wilkinson, 2018), in which the representation of humanism refers to the emphatic, genuine and responsive attitude (Scholl, Hayden \& Clarke, 2017). The humanistic figure can comfort the counselee in the interaction particularly in the feminist counseling setting, in which the dimension of equity becomes a main factor.

The profile of gender roles in the community based on the aspect of character and roles have a larger meaning compared to the aspect of physical and status attributes. The physical and status attributes tend to be unable to shift into more neutral roles. The fundamental point determining the absence of the shift is due to the physical attribute aspect that becomes the raw image of men and women. Besides, a belief that men are the leaders tend to affirm that the status of women is not equal. The results in the study showed that critical analysis is needed for gender equality when it is seen from the religious perspective. The effort to shift from the traditional role needs to consider the cultural perspectives (Constantine, 2007; Tzou, 2012). The concept of equity attempts to eliminate gender bias. The implementation of the equity concept in the liberal feminist perspective is to minimize the gender 
bias caused by the existence of the traditional roles of gender (Corey, 2009). Bias defined here appears in the characteristics related to the competence of men commonly called as agentic characteristic/structural power, while the characteristics of women related to the attention to understand the feeling of other people are called as the communal or expressive/dyadic power (Diekman, et al., 2004). The gender roles of men in the perspective of existentialism refer to success, power, and competing (Schermer \& Holmes, 2018). The counselor is expected to have an understanding of the gender roles by the cultural background of the counselee. Without any understanding of gender roles, the counselor will find it difficult to build a culturally sensitive service (Lee, 2007; Chao, 2012; Tzou, 2012).

The experiment process of F-SFC approach undeniably is focused on the problem of gender; hence, the proportion between the problem and solution (problem-focused or solution-focused) becomes a threat. The use of F-SFC also faces the difficulties particularly when the topic of discussion is not focused. To prevent such threat, the counseling process uses the cutting technique. This is as recommended by Jacobs et.al. (2012) suggesting the counselor to undoubtedly do cutting and interruption when the talk has been out of focus. This is not something simple to be applied in the counseling process. Nevertheless, SFC does not refute the existence of problems but provides the solution to be more concerned in the group discussion (Sharry, 2007).

The procedure of hypothesis test requires the pre-requirement test of analysis to ensure the fulfilment of inferential statistic norms. It can be seen that the results of the posttest analysis in both experiment group and control group had no significant differences. This can be seen from the mean scores of both groups $(\mathrm{F}-\mathrm{SFC}=\mathbf{2 7 7 . 9 3}$ and psycho-education $=278.97)$. The mean difference between the F-SFGC and PG groups was 1.04 viewed very small for the difference between the two means, but the presence of pretest score was assumed to have an impact on the posttest score. The assumption needs to be statistically proven. The pretest variable was controlled to see the extent impact of the treatment on the increase of gender equality in both groups. To control the pretest effect, the statistical analysis chosen was ANCOVA to control the pretest, so that it can be concluded that the changes were due to the treatment not influenced by the pretest. Besides, the analysis also aimed to reduce the threat of the validity of statistical conclusions, i.e. low statistical power. The type of ANCOVA chosen was SS type III, which performed an assumption test to determine the interaction between the pretest and the group (treatment) and then tests the effect of treatment on the dependent variable.

The findings in the counseling process showed the competence in exploring the answers of the question of exception, miracle and scaling. The competence of group members in responding to the question of exception was quite varied as it was in line with the condition of their household. The efforts to integrate both approaches become an opportunity to cope with the problems in gender inequality. The results of the research showed that the principles in the solution-focused counseling approach could be applied; meanwhile, in the feminist counseling approach has been existed in the method of gender role analysis. In practice, both approaches can no longer be used simultaneously as in the phase of analysis of gender role, it could not be directed to make the solution for the problem of gender roles.

The psychoeducation approach and feminist-solution focused counseling approach in this research focused on understanding gender equality. Psychoeducation was in a large group; while, FSFC was in a small one. The effort to guarantee the solution-focused group work in a harmonious situation needs to be focused by the factors of the impulse of a group, learning in a group, optimism of group, chance to help other people and group empowerment (Sharry, 2007). A good group has a balance in communication among the members. Hence, to guarantee the success of group counseling, there is a need to involve the type of groups that tends to be pessimistic and over criticizing and lack of contribution in giving problem solution.

The counselling was focused on what was not wanted by the counselee, in which the discussion of problems aims to explore the things that must be changed and must not be changed. The efforts to cope with the problems were designed using the group strategy to obtain the input from the other members of the group. Sharry (2007) affirmed that facing the problems individually is seen to be unable 
to make any changes. By comparing the process of F-SFC and psychoeducation, both approaches are more acceptable for society. The cultural background is assumed as one of the factors in receiving the information. On the other side, the discussion of culture becomes one of the activities used in coping with the problems either in a family or in community.

\section{Conclusion}

The feminist-solution focused counseling and the psychoeducational group had both advantages and disadvantages in increasing the understanding of the gender equality. The analysis based on practical significance is to increase the understanding of the gender equality; hence, the psychoeducational group should be compared to the feminist-solution focused approach. However, to build awareness and to develop social skills, the F-SFC approach was found better than the psychoeducational model. The analysis method of gender roles, exception, and miracle can help the counselees to increase their understanding of gender equality.

\section{References}

Azwar, S. (2012). Penyusunan skala psikologi ( $2^{\text {nd }}$ ed). Yogyakarta: Pustaka Pelajar.

Balkin, Richard S. and Schmit, Erika L. (2018). "A humanistic framework using nonlinear analysis to evaluate the working alliance and coping for adolescents in crisis. Journal of Humanistic Counseling. April 2018. Vol. 57, p. 2-13.

Biasi et.al. (2020). The Combined Application of MMPI-2 and OQ-45 to Detect and Measure the Effectiveness of Psychological University Counselling. Journal of Educational and Social Research. Doi: 10.36941/jesr-2020o041. Vol. 10 No 3 May 2020.

Blocher, D. H. (1974). Developmental counseling. Second edition. New York: John Wiley \& Sons, Inc.

Bore, Samuel K; Hendricks, LaVelle \& Womack, Ashley. (2013). Psychoeducational groups in schools: the intervention of choice. National Forum Journal of Counseling and Addiction, 2013. (2), No. 1, p. 1-9.

Briere, John and Jordan, Carol E. (2004). "Violence against Women Outcome Complexity and Implications for Assessment and Treatment". Journal of Interpersonal Violence. 19, 11, 1252-1276.

Brown, Nina W. (2004). Psychoeducational groups: process and practice. Brunner-Routledge. New York and Hove.

Chao, R-C. L. (2012). Racial/ethnic identity, gender-role attitude, and multicultural counseling competence: the role of multicultural counseling training. Journal of Counseling \& Development. January 2012. (90), p. 35-90.

Constantine, Madonna G;Hage, Sally M;Kindaichi, Mai M;Bryant, Rhonda M. (2007). "Social Justice and Multicultural Issues: Implications for the practice and training of counselors and counseling psychologist. Journal of Counseling and Development: JCD; Winter 2007; 85, 1; 24-29.

Corey, G. (2009). Theory and practice of counseling and psychotherapy. Eighth Edition. Belmont, CA: Brooks/ColeThomson Learning.

Creswell, J. W. \& Clark, V. L. P. (2007). Designing and conducting mixed methods research. California : Sage Publications, Inc.

Creswell, J. W. (2009). Research design; qualitative, quantitative, and mixed methods approaches. Third edition. Thousand Oaks: Sage Publications, Inc.

Crethar, H. C; Rivera, E. T \& Nash, N. (2008). In search of common threads: linking multicultural, feminist, and social justice counseling paradigms. Journal of Counseling and Development: JCD; Summer 2008; 86, (3), p. 269-278.

Dermer, Shannon B; Hemesath, Crystal Wilhite \& Russel, Candyce. S. (1998). A feminist critique of solution-focused therapy. The American Journal of Family Therapy. 266, (3), p. 239-250.

Diekman, Amanda B., Goodfriend, Wind \& Goodwin, Stephanie. (2004). "Dynamic Stereotypes of Power: Perceived Change and Stability in Gender Hierarchies". Sex Roles. February 2004. 50, (3/4), 201-215.

Dimmitt, C; Carey, J. C; McGannon, W. \& Henningson, I. (2005). Identifying a school counseling research agenda: A Delphi study. Counselor Education and Supervision; ProQuest Education Journals. Mar 2005; 44, (3), p. 214-228.

Evans, Kathy M; Kincade, Elizabeth A; Marbley, Aretha F; Seem, Susan R. (2005). "Feminism and Feminist Therapy: Lesson from the Past and Hopes for the Future". Journal of Counseling and Development: JCD. Summer 2005. 83, 269-277.

Franklin, C; Moore, K \& Hopson, L. (2008). Effectiveness of solution-focused brief therapy in a school setting. Children \& Schools. ProQuest. Jan 2008 (30) p. 15-26.

Furqon. (2009). Statistika terapan untuk penelitian. Bandung: Alfa Beta. 
Grant, A.M. \& O'Connor, S.A. (2010). The differential effects of solution-focused and problem-focused coaching questions: a pilot study with implications for practice. Industrial and commercial training. (42), 2, p.102-111.

Grant, Anthony M. (2012). Making positive change: a randomized study comparing solution-focused vs. problemfocused coaching questions. Journal of Systemic Therapies. 2012 (31) p. 21-35.

Hackney, H. L. \& Cormier, S. (2009). The professional counsellor: A process guide to helping. (Sixth edition). New Jersey: Pearson Education, Inc.

Hall, K. R., Rushing, J. L., \& Khurshid, A. (2011). Using the solving problems together psychoeducational group counseling model as an intervention for negative peer pressure. The Journal for Specialists in Group Work. (36) No. 2, June 2011, p. 97-110.

Healey, Amanda C. \& Hays, Danica G. (2012). "A Discriminant Analysis of Gender and Counselor Professional Identity Development”. Journal of Counseling E Development. January 2012, 90, 55-62.

Heppner, P. P.; Wampold, B. E. \& Kivlighan Jr., D. M. (20o8). Research design in counseling. Third Edition. Belmont, CA: Thomson Brooks/Cole.

Hermawati, T. (2007). Budaya Jawa dan kesetaraan gender. Jurnal Komunikasi Massa. 1, (1), p. 18-24.

Hoffman, R. M. (2001). The measurement of masculinity and femininity: historical perspective and implications in counseling. Journal of Counseling and Development: JCD. [Online], 79, (4) pp. 472-485. Available at: http://www.proquest/pqdweb. [accessed in 12 May 2006].

Hsu, W. S. \& Wang, C. D. C. (2011). Integrating Asian clients filial piety beliefs into solution-focused brief therapy. International Journal Adv Counselling. (33), p. 322-334.

Jacobs, Ed. E.; Masson, R. L.; Harvill, R. L. \& Schimmel, C. J. (2012). Group counselling; strategies and skills. Seventh edition. Belmont: Brooks/Cole.

Kercheval, Jacquelyn; Markowitz, Daniel \& Monson, Katherine. (2012) Women in leadership: Research on Barriers to Employment and Decent Work for Women. International Labour Office. Jakarta: ILO.

Lee, M. Y. (2003). Cultural and spiritual perspectives; a solution-focused approach to cross-cultural clinical social work practice: utilizing cultural strengths. Families in Society: The Journal of Contemporary Human Services. Jul-Sep 2003, (84), p. 385-395.

Lee, M. Y.; Uken, A. \& Sebold, J. (2004). Accountability for change: solution-focused treatment with domestic violence offenders. Families in Society. Oct-Dec 2004, (85), p. 463-475.

Lee, W. M. L.; Blando, J. A.; Mizelle, N. D. \& Orozco, G. L. (2007) Introduction to multicultural counseling for helping professionals. Second edition. New York: Routledge Taylor \& Francis Group.

Lukens, Ellen P., \& McFarlane, William R. (2004). Psychoeducation as Evidence-Based Practice; Considerations for Practice Research, and Policy. Brief Treatment and Crisis Intervention (4), No. 3, p. 205-225.

McKenna, J. \& Jones, W. M. (2004). How solution focused support helps women through work-home conflict. Health Education. (104), p. 132-142.

Miles, Matthew B. \& Huberman, A. Michael. (1984). Qualitative data analysis; a sourcebook of new methods. California: Sage Publications, Inc.

Mireau, R. \& Inch, R. (2009). Brief solution-focused counseling: a practical effective strategy for dealing with wait lists in community-based mental health services. Social Work. Jan 2009, (54), p. 63-70.

Nasution et.al. (2020). Dynamics of Resilience on Women as Intimate Partner Violence Survivors. Journal of Educational and Social Research. Doi: 10.36941/jesr-2020-0054. Vol. 10 No 3 May 2020.

Local Government of Bantul. (2015). Laporan Kinerja (LKj) Pemerintah Kabupaten Bantul Tahun 2014. Local Government of Bantul. Special District of Yogyakarta.

Pratikta. (2020). Mindfulness as an effective technique for various psychological problems: A conceptual and literature review. Journal of Professionals in Guidance and Counseling. Available online at: https://journal.uny.ac.id/index.php/progcouns1. (1), 2020, 1-13.

Reiter, Michael D. (2010). Solution-focused marathon sessions. Journal of Systemic Therapies. 2010 (29) p. $33-49$.

Schermer, T.W \& Holmes. C.N. (2018). Will to Masculinity: An Existential Examination of Men's Issues. Journal of Humanistic Counseling. DOI: 10.1002/johc.12082. October 2018. Volume 57. p. 191-207.

Schermer, Travis W. \& Holmes, Cornelius N. (2018). "Will to Masculinity: An Existential Examination of Men's Issues". Journal of Humanistic Counseling. July 2018. Vol. 57, p. 191-207.

Scholl, Mark B; Hayden, Seth C. W. \& Clarke, Philip B. (2017). "Promoting Optimal Student Engagement in Online Counseling Courses”. Journal of Humanistic Counseling. October 2017. Vol. 56, p. 197-210.

Sharf, R. S. (2012). Theories of psychotherapy and counseling; concepts and cases. 5th edition. Belmon, CA: Brooks/Cole.

Sharry, J. (2007). Solution-focused group work. London: SAGE Publications, Ltd.

Shavelson, Richard J. (1988). Statistical Reasoning for the Behavioral Sciences. Needham Heights. Allyn and Bacon, Inc. 
Smith, Paul H. (2018). "Postcolonial Theory and Humanism: A Framework for International Work in the Counseling Profession”. Journal of Humanistic Counseling. July 2018. Vol. 57, p. 138-152.

Smock, S. A. (2008). Solution-focused group therapy for level 1 substance abuser. Journal of Marital and Family Therapy. Jan 2008, (34), p. 107-120.

Söderberg et.al. (2020). Study Demands, Social Support and Mental Health in Teacher Education Students: A CrossSectional Study. Journal of Educational and Social Research. Doi: 10.36941/jesr-2020-0040. Vol. 10 No 3 May 2020.

Trepper, Terry S; Dolan, Yvonne; McCollum, Eric E; \& Nelson, Thorana. (2006). De Shazer and the future of solutionfocused therapy. Journal of Marital and Family Therapy. ProQuest. Apr 2006 (32) p. 133-139.

Tzou, Jean Yuh-Jin; Kim, Eunha \& Waldheim, Kim. (2012). Theory and practice of positive feminist therapy: a culturally responsive approach to divorce therapy with Chinese women. International Journal Adv. Counselling. 2012, (34) p.143-158.

Vela, Javier Cavazos; Smith, Wayne D; Guerra, Federico; Hinojosa, Karina; Aquila, Julia Dell' \& Ortega, Krystle. (2018). "Understanding Humanistic and Family Predictors of Mexican American College Students' Subjective Happiness”. Journal of Humanistic Counseling. April 2018. Vol. 57, p. 51-69.

Widhiarso, W. (2010a). Analisis Kovarian dalam Psikologi Eksperimen. Unpublished Manuscript. Faculty of Psychology UGM, Yogyakarta. [Online]. Available: http://widhiarso.staff.ugm.ac.id/files/Analisis \%2oKovarian\%2odalam\%2oPsikologi\%2oEksperimen.pdf. Accessed in 20 April 2016.

Widhiarso, W. (2010b). Membaca angka pada SPSS. Unpublished Manuscript. Faculty of Psychology UGM, Yogyakarta. [Online]. Available at: http://widhiarso.staff.ugm.ac.id/files/Membaca\%2oAngka \%2opada\%2oSPSS.pdf. Accessed in 20 April 2016.

Widhiarso, W. (2011). Mengaplikasikan uji-t untuk membandingkan gain score antar kelompok dalam eksperimen. [Online]. Available; http://webcache.googleusercontent.com/search?q=cache:Oz5v6_EZVnkJ:widhiarso.staff .ugm.ac.id/files/Mengaplikasikan\%2520Uji-t\%2520untuk\%252oMenguji\%2520Gain\%2520 Score.pdf $+\& c d=1 \& h l=e n \& c t=c l n k \& g l=i d$. Accessed in 20 April 2016.

Wilkinson, Brett D. (2018). "The Limits of Neuroscience in Counseling: A Humanistic Perspective and Proposed Model". Journal of Humanistic Counseling. April 2018. Vol. 57, p. 70-78.

Worell, J. \& Remer, P. (2003). Feminist perspectives in therapy. empowering diverse women. Second edition. New Jersey: John Wiley \& Sons, Inc. 